\title{
Moral and Political Accountability of Local Representatives Body in Indonesia
}

\author{
Inna Junaenah \\ Department of Constitutional Law \\ Universitas Padjadjaran \\ Bandung - Indonesia \\ inna_padjajaran@yahoo.co.id
}

\begin{abstract}
Collectively, Local Representatives Body (Dewan Perwakilan Rakyat Daerah-DPRD) in Indonesia has function in by-laws making, supervision, and budgeting. Elaborating these functions, laws determine the rights and duties of member of DPRD in distorted way. Particularly, the member of DPRD has rights to initiate bill of by-laws, asking some questions, and arguing idea and opinion. Meanwhile, they have particular duties to transform people aspiration into policy and express both moral and political accountability to the constituent. In this paper, I would like to highlight that the duty to deliver accountability is understood as voluntary provision, not embodied to bind councilor's behavior.
\end{abstract}

Keywords-disparity, DPRD, individual accountability

\section{INTRODUCTION}

Political accountability to achieve substantive democracy must be contextual with the function and responsibility of Local Representatives Body (Dewan Perwakilan Rakyat Daerah, so-called DPRD) in Indonesia. The reason is simple: nominated by political party in elected time, DPRD individually represent a number of people who shall continuing common interest through representatives. Collectively, Local Representatives Body (Dewan Perwakilan Rakyat Daerah-DPRD) in Indonesia has function in local ordinance so-called by-laws or Peraturan Daerah (Perda) making, supervision, and budgeting. This provisions are dynamically written in The Act of Republic of Indonesia Number 27 Year 2009 and replaced by The Act of Republic of Indonesia Number 17 Year 2014 (Art 365 and 366). The three functions are exerted to establish people representativeness in local entities. Normatively, the function in by-laws making itself is a replaced terminology from legislation function. Under this function, DPRD has responsibility to make by-laws altogether with head of local government; and process debate and approve the bill on local budget proposed by head of local government (Art 366). Both Law on MPR, DPR, DPD, and DPRD (popularly being called as Act on MD3) and Law on Local Government 2014 elaborate the rights and duties of DPRD either in Province or Municipality. Particularly, the member of DPRD has rights to initiate bill of by-laws, delivering some questions, and arguing idea and opinion.

Elaborating these functions, laws determine the rights and duties of member of DPRD in distorted way. Institutionally,
DPRD has interpellation, questioning, and delivering opinion rights. Meanwhile, individually member of DPRD has rights to a) recommend the bill; b) asking some questions; c) release the proposal and opinion; d) vote and to be voted; e) selfdefense; f) immunity; g) participate in coaching and duty indepth; h) protocollary; and i) financial and administrative scheme.

Of the number of duties, only in complying the code of conduct a member of DPRD is possible to be measured $(\mathrm{g})$. The others, particularly the duties to transform people aspiration into policy and express both moral and political responsiveness to the constituent is not exercised by implemented instrument, whereas these responsibilities meet the significant accountability the most. There might be two possible impact of such provision: first, for it is hard to appraise moral and political responsiveness, the clause could be understood as a voluntary phrase. Two, if it is realized as some binding responsibilities, DPRD may possibly improve to integrate those commitments into such code of conduct (tata tertib DPRD).

In this paper, I would like to highlight that the duty to deliver accountability is only understood as voluntary provision, not embodied to bind councilor's (member of DPRD) behavior. For this aim, I would address two questions: a) what is the indication of inconsistency the right and duty of member of DPRD? In what way DPRD could be encouraged to embody moral and political accountability? Several legislations, reports, journal articles, and sort of documents related on DPRD and political accountability are constructive to shape opinion on those two questions in this paper.

\section{RESULTS AND DISCUSSION}

\section{A. Inconsistency on the Right and Duty of Member of DPRD}

Based on Act of MD3, during the period the member of DPRD shall comply the code of conduct rendered by each DPRD institutionally. By the norms herein every councilor is expected to maintain each dignity, nobility, reputation, and credibility (Art 377 Act on MD3). To some extent, function and responsibility for representative body are might be the most significant devices to identify councilor's performance valued in accountability. Inappropriately, the existing code of conduct has not revealed neither a sequence or encouragement on accountability in legislative function particularly. Measuring accountability for DPRD as local councilor is not 
as regular as counting the executive performance mechanism, for it is run daily. [1] Let's see some ideas supporting the function and responsibility of local representatives under "the representative's government and specially "local representativeness".

In "the representative's government theory" vary element of citizen is necessary have access to participate in all of branch of government. Ones obliquely identify the pattern of grouping representative government with direct and indirect democracy (representative democracy), so there could be direct and indirect government (representative government). [1] However, the nature of direct and indirect government is only a blurred distinction. [1] Nevertheless, the important thing is the purpose of the legitimate government, affirmed by John Stuart Mill affirm, are to improve "the virtue and intelligence of the people under its jurisdiction", and to organize "such good qualities of the people as currently exist to promote as far as possible the long-run common good". [1] Either in the term "representation" or whatever name scholars give it, the crucial thing is how the elements herein can be analyzed and the consequences can be observed. Therefore, Bernard Manin asserts four principles representative regimes, ever since this form of government was invented: "1) Those who govern are appointed by election at regular intervals. 2) The decision-making of those who govern retains a degree of independence from the wishes of the electorate. 3) Those who are governed may give expression to their opinions and political wishes without these being subject to the control of those who govern. 4) Public decisions undergo the trial of debate". Manin claims that those principles of representative government are observed from the time of its invention to the present day. [1, p. 6]

Some common mechanism of recruitment to establish ruling government involve political party. National Democratic Institute illustrates where political party head their candidates in branches of government as follows:

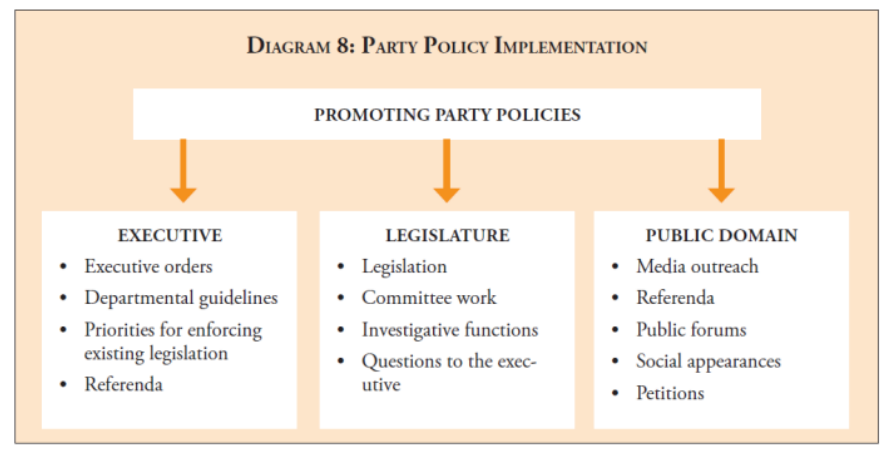

Fig. 1. Party Policy Implementation

Relating the four principles and the diagram [3], I would underline that those principles must be alternative, not a cumulative condition on representative government. The reason is considered from the fact that in Indonesia, some who govern are elected by citizen and others are appointed involving public opinion through debate. This is the particular position of local representative body recognized in
International Union of Local Authority (IULA) World Wide Declaration of Local Government, Toronto, June 1993. The Declaration denotes representative bodies freely elected on a periodical basis by equal, universal suffrage, as particular agent to exercise the right and the duty of local authorities (Art. 1 and 2). [3] Is the right and duty of local representative body divided between collective and individual manners, the Declaration does not elaborate in detail. There might an intention on individual the more rather than collective responsibility of local councilor, for Suzzane Dovi presents the current practice of empirical political scientists assuming that "good representation should be delegates, not trustees or, in other words, that good representatives are ones who obey the policy preferences of a majority of their constituents" in drawing correlations between representatives and constituents to measure representativeness. For that reason, I convince that the notion of representativeness is personal. At the fact, why in representative the liability is identified as collective collegial is only to achieve the "answerability" to produce some collective and consensus conclusion.

In this sense, the element to achieve some productivity of Peraturan Daerah-Perda, specifically by initiative of DPRD is approached in Indonesian Democracy Index (IDI). It quantifies the percentage productivity of DPRD to the amount of passed Perda. [5] UNDP Indonesia considers this productivity based on the idea that civil liberties and political right as the pillar of democracy must be actualized optimally under democratic institutional. [5, p. 20] For instance, in West Java Province, of the twelve issued Perda in 2015 there are only two Perda coming from DPRD's initiative. Additionally, there are only thirteen recommendation addressed to local authority during one year working (2015). [6] This measurement might be debatable in concept, for the debate process in formulating Perda is necessary to get respect as achievement as well. Nevertheless, the condition still demonstrates the low performance of DPRD, since they personally cannot afford to bridge the constituency aspiration into the proposal of regulation. Moreover, there is no adequate information on rule of conduct of DPRD of West Java Province in its website, unless mentioning the two of duplicated formulation of the rights and duties in the Act on MD3. These limited norms eliminate the possibility to reveal accountability in other aspect such of attendance and declaration in a meeting. Once, 67 of 98 members of DPRD was absent in full meeting in which "The Report on Recess 1 Phase II Year 2015" would be delivered (Friday, 14 ${ }^{\text {th }}$ August). Subsequently, the assembling was being rescheduled as it did not accomplish the quorum. [7]

In this sense, DPRD of City of Bandung might be better. In the website, the reader could find the rule of conduct in which every councilor is obliged to attend the assemblies, numerous the rights and duties are written collectively and individually, and even mechanism of recall is standardized. [8] I supposed that those provisions have risen a result, particularly by a claim that the average attendance reached $80 \%$. [8] In contrast, DRPD throw the record of productivity decrease of Perda to 
Mayor and his organization since there are only less bill of Perda proposed to be discussed. This paradigm point immobilized rights of DPRD to initiate a bill of Perda. Strictly saying, this condition remains some problems. The provision on rule of conduct provides less mechanism to embody the duty of member of DPRD to absorb public aspiration and to distribute moral and political accountability. Supplying only mechanism of recall under political party opinion explains the strong connection with political party the more rather than with the citizen. It indicates that performance of DPRD is necessary emerge in two sides: collectively and individually. The reason is that public trust forward on those ways. Drawing public trust on representative body in Indonesia might be began with examining The House of Representatives (DPR). Only for illustration, statistically press is more trusted rather than DPR. [10] Therefore, the potential elaboration of misuse of the rights and duties of DPRD lies on appearance in the assembly, exploring some ideas, and unidentified budget spending.

\section{B. Embodying Moral and Political Accountability}

Why accountability always has been central to democratic theory, Staffan I. Lindberg convinces that democracy necessitates accountability. [2] according to Linberg, in political accountability, the people's representatives render account to the voters for the Voters delegate their sovereignty to popular representatives at election time. [3, p. 15] What aspects of accountability shall people's representatives apply? It definitely relies on what typical of accountability is addressed. Political and administrative accountability by alone, frequently involve several aspects, so Bovens also familiarized the category accountability generally detailed as follows:

- Based on the nature of the forum, accountability is classified in: political accountability; legal accountability; administrative accountability; social accountability.

- Based on the nature of the actor, accountability is classified in: corporate accountability; hierarchical accountability; collective accountability; individual accountability.

- Based on the nature of the conduct, accountability is classified in: financial accountability; procedural accountability; product accountability.

- Based on the nature of the obligation, accountability is classified in: vertical accountability; diagonal accountability; horizontal accountability. [13]

Applying this classification based on the nature of the forum, accountability of DPRD is the sort of political, legal, and social accountability. Included in political accountability, obviously because DPRD is nominated by political party. David Minja believes that accountability involves both the political justification of decisions and actions and managerial answerability for implementation of those decisions and agreed tasks according to agreed criteria of performance. [1] For Minja, effective accountability is not just about reporting performance; it also requires review, including appropriate corrective actions and consequences for individuals. [1] it is also said in legal accountability for the rights and duties under the law provisions, and being social accountability as DPRD should feel obliged to account for their performance to the public at large.

Second, based on the nature of the actor, accountability of DPRD is sorted in collective and individual accountability. Communally, representative body might have legislative function mandated to create some good regulation both in quality and in quantity. One might be an indication is the question on regulation issuing popular (pro public), repressive (including taxation demand) for people, or elitist matters such as budgeting, and staffing? Those things much or less are affordable to observe the activity of representative body. Bovens notes two main weaknesses of collective accountability: first, "the major difficulty with collective accountability lies with its moral appropriateness", and "they are not sophisticated enough to do justice to the many differences that are important in the imputation of guilt, shame, and blame". [3, p. 18] These demerits of accountability might answer by another Bovens's classification so-called individual accountability. Individually, for an accountability regime is a coherent complex of arrangements and relationships, [13] individual political accountability encompasses a system of interconnected, standardized forms of accountability, including obligations to inform, interpellations, parliamentary debates and inquiries. In this sense, "an individual accountability in which each individual official is held proportionately liable for his personal contribution to the infamous conduct of the organization, is from a moral standpoint a far more adequate strategy". [3, p. 19] As written previously, potential elaboration of misuse of the rights and duties of DPRD lies on appearance in the assembly, exploring some ideas, and unidentified budget spending. This identification appears both moral and political accountability of DPRD is distributed on input, process, and output scheme. I would classify the scheme below:

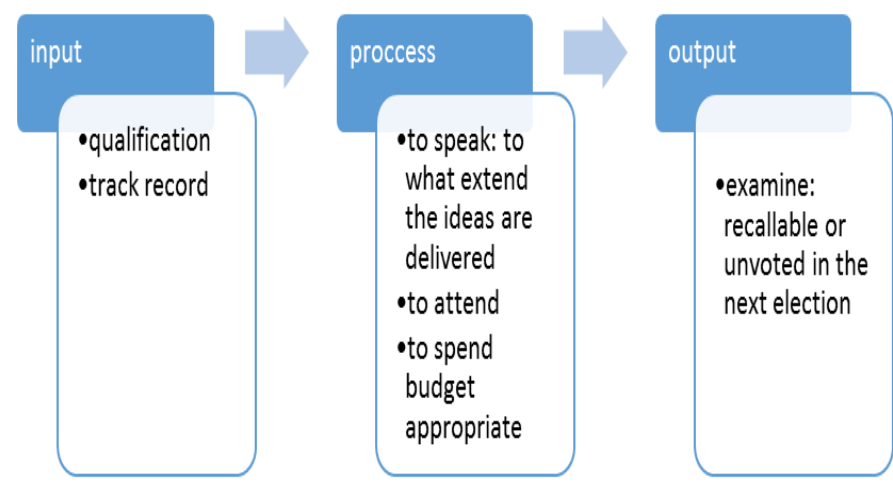

Fig. 2. Scheme on Accountability of Representative Bodies

A candidate of representatives must be answerable in encountering qualification and track record issues. In representative democracy recognized that not all people are eligible to adjust in assembly. In input scheme, candidates should meet the qualification to promise that this honorable 
person will fight for society. After elected, constituent necessitates to watch the participation of representatives in pursuing their ideas. In other words, they are capable to speak, so people can examine to what extend the ideas are delivered. A minimum standard in what is the mapping of attendance percentage. In financial management, counselors must prove that they spend budget appropriately. For those perception, legislative function should be understood as a daily task. If in this process the elected representative is not perform, output mechanism requires a recall standardized clearly in two ways: recallable either by political party or constituent or unvoted in the next election. Third, based on the nature of the conduct, accountability of DPRD is classified as financial or procedural accountability when the propriety of financial management by DPRD is at risk. I note that DPRD shall not be trapped in procedural financial limitation, otherwise they cannot discover some potential issues to be fight in assembly. The most important here is to inquire what bill may possibly be proposed, debated, and passed, so this is the product accountability group. The last, based on the nature of the obligation accountability for DPRD is classified in horizontal accountability the most, since "the obligation felt by agencies to publicly account for themselves is moral in nature, and not based on legal requirements". [13] I underline that accountability is a contract, a commitment, a personal promise. [13, p. 12] In this sense, disparity is not reflected between a member of local representative's body and another actor, but on the provisions on the right and the duty of local representatives individually. Law maker made an imbalance and inconsistence appearing the right are larger rather than the duty of local council.

After all, where the moral aspect is lied on political accountability? Practiced effectively, accountability in Bovens's explanation "is a way of thinking and acting all the time and ultimately trumps any financial, intellectual, structural, or technological ability". [13, p. 12] The reason is simple: accountability is not based on circumstance but rather on an attitude of accomplishing a task or achieving an objective. Considered as critical to anyone leading a group of people, because, those who elected must realize that every business is a people business: accomplished or not accomplished. [15, p. 12]

Presenting those of accountability craves the role of publicity to open those behaviours. In decentralization perspective, James Manor relate this effort to three essential things to emerge democratic decentralization: "substantial powers must be devolved onto elected bodies at lower levels, substantial resources much be devolved onto them, and accountability mechanisms must be developed to ensure two kinds of accountability: the horizontal accountability of bureaucrats to elected representatives, and the downward accountability of elected representatives to ordinary people". [16] The third character requires the member of DPRD in two variables: DPRD shall develop themselves in order to accept bureaucrat's accountability and being accountable before the citizen.
Why the constituent might demand moral accountability? James Fieser identifies the closest term "moral" is "ethics" used interchangeably. Ethics is defined as "a theory or system dealing with values relating to human conduct, with respect to the rightness and wrongness of certain actions and to the goodness and badness of the motives and ends of such actions". [16] Henry Hazlitt reminds us that in primitive societies religion, morals, law, customs, manners, exist as an identical whole. The remarkable description of the blending and division of the area of ethics, law, and theology is the raise of the doctrine of Natural Law. [18] In Hazlitt annotation, Roman lawyers develop Greek develop theories on what was right by nature and what was right by convention or enactment highlight a distinction between law by nature and law by custom or enactment. [19, p. 62] In other words, "positive law and "positive" morality are both products of a long historical growth". [19, p. 64] Eventually, this distinction could not be separated in rigid way, for in ethics as in law, the traditional and accepted rule is to be followed unless there are clear and strong reasons against it. Each moral rule must be judged in accordance with its utility, but some moral rules have this utility simply because they are already accepted. [19, p. 71] The problem in Indonesia is what morally is accepted in ordinary people and idealist scholars might not acceptable enough pragmatically. This gap appears some unrespectable strengthened by the prove that particular representatives are allegedly in corruptive behavior

Previously stated that being representation, member of DPRD should maintain public trust. For this reason, Bagir Manan asserts four sources of honorability of representative body: elected directly, privilege and immunity, rule of conduct, and rule of law. [10, pp. 3-5] First, being elected as representatives shall be apprehended not only because of majority gains, but public trust as well. Second, privilege might be understood as the right to be prior. Nonetheless, Bagir Manan emphasizes that an honorability must be followed by obligation. Meanwhile, immunity sometime is used to exclude representatives from the certain legal responsibility, but also as the method to preserve an honorability. Third, rule of conduct is the collection of duties that a public officer must respect. This instrument, Bagir Manan convinces, is the method to examine public respect. Fourth, relying on rule of law the mechanism to preserve public respect might be directed. Moreover, Bagir Manan expands the source of public respect on representatives on integrity, political responsibility and deep comprehension, educated manners, and faithfulness as a way of life. [10, p. 6] In this development, accountability could be encouraged as particular device to preserve public respect on representatives.

In England parliament, the identical source of public respect is detained in seven principles of public life.[8] Principle one is selflessness, means that "holders of public office should act solely in terms of the public interest". Principle two is integrity, means that "holders of public office must avoid placing themselves under any obligation to people or organizations that might try inappropriately to influence them in their work. They should not act or take decisions in 
order to gain financial or other material benefits for themselves, their family, or their friends. They must declare and resolve any interests and relationships". Principle three is objectivity, means that "holders of public office must act and take decisions impartially, fairly and on merit, using the best evidence and without discrimination or bias". Principle four is accountability, means that "holders of public office are accountable to the public for their decisions and actions and must submit themselves to the scrutiny necessary to ensure this". Principle five is openness, means that "holders of public office should act and take decisions in an open and transparent manner. Information should not be withheld from the public unless there are clear and lawful reasons for so doing". Principle six is honesty, means that "holders of public office should be truthful". And the last principle is leadership, means that "holders of public office should exhibit these principles in their own behavior. They should actively promote and robustly support the principles and be willing to challenge poor behavior wherever it occurs". Inspired by those principles, Bagir Manan underlines that ethics is an individual requirement on the obligation of what must be fulfilled by those who govern. Inevitably, public officer cannot be separated of environment system, such as social, culture, government, economy, and so forth. Environment in which the paradigm "money can buy" is legitimated will distract ethics and accountability. [9]

\section{CONCLUSION}

To summarize this paper, I would like to argue that disparity of right and duty of DPRD is not about the reflection between a member of local representative's body and another actor, but on the provisions on the right and the duty of local representatives individually. Law maker made an imbalance and inconsistence appearing the right are larger rather than the duty of local council. As far as there is not some revised provisions, normatively, moral and political accountability is necessary encouraged by ethical standard. Nevertheless, this effort might not adaptive enough for professionalism of local representative's member. Particularly in Indonesia, local politicians come from vary entry background of knowledge and profession. Therefore, citizen necessitates a standardized implementation to bridge between the right and duty and the moral and political accountability.

\section{REFERENCES}

[1] S. D. Harijanti, "Academic Draft on Accountability of Constitutional Holder (Naskah Akademik RUU Akuntabilitas Penyelenggara Negara)," Kedeputian Pengawasan dan Akuntabilitas Aparatur Kementerian Pendayagunaan Aparatur Negara (PAN), Jakarta, 2011.

[2] B. Manin, The principles of representative government, Paris: Cambridge University Press, 1997, p. 5.

[3] J. S. Mill, JOHN STUART MILL, Considerations on Representative Government, UC San Diego Department of Philosophy, 2006, p. 4.

[4] N. D. Institute, "Developing party policies," Washington, 2013.

[5] I. U. o. L. A. (. W. W. D. o. L. Government. [Online]. Available: http://www.bunken.nga.gr.jp/siryousitu/eturansitu/charter/iula_decl_txt. html. [Accessed 1310 2016].
[6] M. R. (et.al), "Measuring Democracy in Indonesia: Indonesian Democracy Index 2009 (Menakar Demokrasi di Indonesia: Indeks Demokrasi Indonesia 2009)," UNDP Indonesia, Jakarta, 2011.

[7] "Newspaper and Document Coding in 2015 (Hasil Koding Koran Dan Dokumen Tahun 2015)," Bandung, 2016.

[8] D. J. Barat, "Rules of conduct of DPRD of West Java Province (Tata Tertib Dprd Provinsi Jawa Barat)," [Online]. Available: http://dprd.jabarprov.go.id/profile/rules,. [Accessed 1810 2016].

[9] "DPRD Kota Bandung," [Online]. Available: http://www.dprdbandungkota.go.id/.

[10] "inilah.com," $28 \quad 52013 . \quad$ [Online]. Available: http://m.inilah.com/news/detail/1993801/dprd-kota-bandung-tetapfokus-jalankan-tugas . [Accessed 1810 2016].

[11] B. Manan, Preserving Public Trust on Representative Bodies (Menjaga Rasa Hormat Publik terhadap Badan Perwakilan Rakyat), Majelis Kehormatan Majelis Kehormatan DPD RI, 2012, p. 2.

[12] S. I. Lindberg, "Accountability: the core concept and its subtypes," Africa Power and Politics Programme (APPP), London, 2009.

[13] M. Bovens, "Public Accountability, A framework for the analysis and assessment of accountability arrangements in the public domain," .," Utrecht.

[14] M. Bovens, "Public Accountability, A framework for the analysis and assessment of accountability arrangements in the public domain," Utrecht.

[15] D. Minja, "Accountability Practice In Kenya'S Public Service: Lessons To Guide Service Improvement," International Journal of Business and Management Review, Vols. Vol.1, No.4, p. 55, 2013.

[16] G. Bustin, Accountability, the Key to Driving a High-Performance Culture, New York, Chicago, etc.: Mc Graw Hill, 2014, p. xiv.

[17] J. Manor, "Perspectives on Decentralization," International Center for Local Government, Visby, Sweden, 2011.

[18] J. Fieser, Ethical Theory, From Moral Issues that Divide Us and Applied Ethics: A Sourcebook, www.utm.edu/staff/jfieser/class, 2008, p. 1.

[19] H. Hazlitt, The Foundations Of Morality, New York: The Foundation for Economic Education Irvington-on-Hudson, 1964.

[20] H. Hazlitt, The Foundations Of Morality.

[21] L. Maer, "Committee on Standards in Public Life," Number 04888, 27 May 2015, p. 5, 27 May 2015.

[22] B. Manan, "Public Agents and Ethics, Etika dan Jabatan Publik," Varia Peradilan, Vols. 369, Year XXXI, p. 16, August 2016

[23] M. Bovens.

[24] S. Project, "Reducing Racial Disparity in the Criminal Justice System: A Manual for Practitioners and Policymakers," The Sentencing Project, Washington DC, 2000.

[25] anonymous, "Cambridge Dictionary," [Online]. Available: http://dictionary.cambridge.org/dictionary/english/disparity. 